\title{
PELATIHAN MANAJEMEN USAHA PEMASARAN PRODUK HOME INDUSTRI TEMPE PADA USAHA MANDIRI WARGA RT. O4 KELURAHAN TALANG JAMBE PALEMBANG
}

\author{
Meilin Veronica ${ }^{1)}$ \\ 1)Fakultas Ekonomi. Jurusan Manajemen, Universitas Indo Global Mandiri \\ Jln. Jenderal Sudirman No. 629 Km 4, Palembang \\ Email : meilin.veronica@uigm.ac.id ${ }^{1)}$
}

\begin{abstract}
ABSTRAK
Pelatihan Manajemen Usaha Pemasaran Produk Home Industri Tempe Pada Usaha Mandiri Warga RT.04 Kelurahan Talang Jambe Palembang diharapkan akan memberikan wawasan baru dalam memasarkan produk tempe melalui kegiatan promosi dan distribusi yang baik. Pemahaman yang baik terhadap kegiatan promosi dan distribusi akan membuat home industry tersebut mendapatkan laba yang tinggi dan berkembang sehingga bisa merekrut tenaga kerja dan dapat mengurangi jumlah pengangguran di sekitaran Kelurahan Talang Jambe. Metode yang diterapkan dalam kegiatan ini adalah Metode presentasi mengenai pengenalan kegiatan promosi dan distribusi. Penerapan kegiatan promosi dengan menggunakan sosial media, menawarkan produk secara gratis, memilih tempat strategis, memberi insentif untuk rekomendasi dan menjalin hubungan baik dengan pelanggan dan penerapan kegiatan distribusi dengan saluran distribusi intensif dimana barang yang dipasarkan bisa menyebarluas dan dapat menjangkau semua lokasi dimana calon konsumen berada. Metode evaluasi dengan mengamati perbedaan sebelum dan setelah pelatihan. Hasil yang dicapai terlihat peningkatan kegiatan promosi dan distribusi yang cukup signifikan dibanding dengan sebelum dilatih, sehingga dapat disimpulkan bahwa kegiatan ini berhasil meningkatkan kemampuan peserta dan memicu motivasi untuk selalu berpikir kreatif dan inovatif. Program pelatihan ini diharapkan terus diadakan pada setiap jenis usaha sejenis karena sangat dirasakan manfaatnya untuk meningkatkan pengetahuan dan pemahaman tentang kegiatan promosi dan distribusi produk.
\end{abstract}

\section{Kata kunci : Pemasaran, Promosi dan Distribusi}

\section{PENDAHULUAN}

Kotler, Kartajaya, dan Setiawan, menyebut pemasaran telah berkembang dari yang semula berorientasi pada produk (marketing 1.0) ke pemasaran berorientasi pada pelanggan (marketing 2.0), lalu pemasaran yang berorientasi pada manusia (marketing 3.0). Pada era marketing 1.0, fokus terletak hanya pada bagaimana menjual produk sebanyak mungkin sedangkan sisi konsumen atau pelanggan tak dipikirkan. Sedang di tahap berikutnya (2.0), perusahaan memasarkan produk sambil menyentuh hati pelanggan. Sebuah brand diupayakan punya ikatan emosional dengan pelanggannya. Pendekatan ini kini juga dianggap ketinggalan zaman lantaran lagi-lagi hanya menganggap konsumen individu yang pasif. Di era setelahnya (3.0), konsumen bukan lagi dianggap obyek-pasif. Konsumen juga manusia yang berdaging, punya akal budi, hati nurani, cita-cita, harapan, dan rasa cemas. Perusahaan tak hanya memasarkan produk, tapi juga punya visi, misi, dan value yang sejalan dengan konsumennya.

Di sini, perusahaan diibaratkan sebagai manusia. Ketika perusahaan menjalankan etika bisnis dengan baik, pelanggan akan menilainya baik yang kemudian produk atau layanannya ia konsumsi. Nah, pendekatan manusiawi pada pelanggan perlu dimutakhirkan seiring perkembangan teknologi yang kian pesat. Marketing tahap keempat atau pemasaran 4.0 memanfaatkan teknologi terkini untuk menyentuh pelanggan secara manusiawi. Dasar pemikiran utamanya adalah pemasaran harus disesuaikan dengan perubahan alami dari jalur pelanggan dalam ekonomi digital. Peran yang diemban pemasar adalah membimbing pelanggan di sepanjang perjalanan mereka dari kesadaran hingga akhirnya penganjuran. Pemasaran adalah Penganalisa, perencanaan, implementasi, dan pengendalian dari program-program yang dirancang untuk menciptakan, membangun dan 
memelihara pertukaran yang menguntungkan dengan pembeli sasaran untuk mencapai tujuan perusahaan menurut Kotler, (2001: 18)

Disamping faktor pemasaran, faktor lain yang tidak kalah pentingnya adalah saluran promosi dan distribusi. Kegiatan promosi yang dilaksanakan dengan baik dapat mempengaruhi konsumen untuk berpikir atau memilih di mana dan bagaimana konsumen harus membelanjakan pendapatannya. Suatu perusahaan harus berusaha mencari media promosi yang tepat digunakan untuk memperkenalkan produk atau jasanya pada konsumen. Promosi dapat membawa keuntungan, baik bagi produsen maupun bagi konsumen. Keuntungan bagi konsumen adalah dapat mengatur pengeluarannya. Hal ini menyebabkan konsumen dapat memilih produk yang sesuai dengan keinginannya. Tujuan perusahaan menggunakan promosi adalah menghindari persaingan harga, sehingga konsumen membeli barang yang perusahaan promosikan karena tertarik pada merknya. Adanya promosi dapat menimbulkan goodwill. Keuntungan selanjutnya bagi perusahaan adalah adanya goodwill yang besar akan lebih mudah mendapatkan modal yang besar.

Menurut Swastha, (2002 : 286) Saluran distribusi berperan sebagai suatu jalur yang dilalui oleh arus barang-barang dari produsen ke perantara dan akhirnya sampai kepada konsumen sebagai pemakai produk yang diproduksi. Syarat-syarat lain yang tidak boleh diabaikan oleh produsen adalah tersedianya produk, agar setiap saat dibutuhkan oleh konsumen yang bersangkutan dapat diperoleh dengan mudah dan cepat. Kealpaan suatu perusahaan untuk dapat menyediakan produknya setiap saat dibutuhkan oleh konsumen, akan menimbulkan konsekuensi bahwa loyalitas konsumen terhadap merk produknya menurun, yang disebabkan karena banyaknya produk subtitusi sempurna yang mempunyai kualitas dan harga yang bersaing dengan produk perusahaan yang bersangkutan. Dengan adanya saluran distribusi yang baik maka penyebaran produk serta jangkauan ke daerah pemasaran semakin luas. Dengan semakin baiknya saluran distribusi yang digunakan oleh produsen terhadap konsumen, maka akan semakin banyak konsumen yang dapat direbut.

Berdasarkan latar belakang tersebut di atas maka Pelatihan Manajemen Usaha Pemasaran Produk Home Industri Tempe Pada Usaha Mandiri Warga RT.04 Kelurahan Talang Jambe Palembang sangat penting untuk diadakan. Pelatihan ini diharapkan akan memberikan wawasan baru dalam memasarkan produk tempe melalui kegiatan promosi dan distribusi yang baik. Adapun home industri tempe yang menjadi sasaran kegiatan kali ini dengan alasan bahwa masih menjalankan kegiatan promosi secara sederhana dari satu konsumen ke konsumen lain dan jalur distribusi yang digunakan masih sedikit karena hanya menjangkau daerah sekitaran Talang Jambe Palembang.

\subsection{Identifikasi Permasalahan}

Setelah melakukan diskusi dan pengamatan kepada usaha home industry Bapak Rohidin yang beralamat di RT.04 Kelurahan Talang Jambe, maka penulis berkesimpulan bahwa usaha tersebut masih kurang dalam hal promosi dan distribusi dan dalam hal ini penulis berkesempatan untuk memberikan pelatihan tentang promosi dan distribusi agar usaha home industry Bapak Rohidin dapat berkembang sehingga bisa merekrut karyawan baru dan mengurangi tenaga kerja pengangguran didaerah tersebut dan menghasilkan laba yang besar

\subsection{Tujuan Kegiatan Pengabdian Pada Masyarakat}

Adapun target yang ingin dicapai pada Program Pengabdian Masyarakat adalah untuk meningkatkan pengembangan usaha yang meliputi :

1. Promosi produk

2. Distribusi produk

Memperhatikan analisis situasi dan penetapan prioritas masalah yang akan diselesaikan selama Program Pengabdian dibagi menjadi tiga tahapan :

1. Formulasi Strategi, perencanaan mengenai kegiatan atau rencana kerja untuk mencapai tujuan

2. Implementasi, Penerapan kegiatan atau rencana kerja yang telah di rumuskan dalam formulasi strategi

3. Evaluasi Penilaian terhadap kegiatan atau rencana kerja apakah berhasil mencapai tujuan atau tidak 


\subsection{Manfaat Kegiatan}

Program pengabdian pada masyarakat ini diharapkan para peserta dapat mengetahui tentang arti pentingnya kegiatan promosi sebagai usaha dalam memperkenalkan produk kepada masyarakat dan juga peran masyarakat dan distribur sebagai jalur distribusi

\section{METODE PELAKSANAAN PENGABDIAN}

Berdasarkan uraian sebelumnya dan hasil diskusi dengan mitra, maka prioritas permasalahan yang harus diselesaikan bersama mitra home industri adalah memperbaiki promosi dan distribusi pada produk hasil home industri.

Tahap I Promosi meliputi usaha yang dilakukan untuk memberi informasi, mempengaruhi dan menjalin hubungan dengan kelompok target anda.

Tahap I Distribusi meliputi pemilihan distributor atau perantara yang sesuai dengan produk.

\section{HASIL DAN PEMBAHASAN}

Materi yang tersajikan mengenai manajemen pemasaran yang disajikan oleh Tim PPM UIGM. Berikut tabel daftar materi dan pematerinya yang telah terlaksana dalam program PPM ini, yaitu :

Tabel 1. Daftar Jenis Kegiatan, Materi, Pemateri, dan Waktu Pelaksanaan

\begin{tabular}{|c|c|c|c|}
\hline $\begin{array}{c}\text { Jenis } \\
\text { Kegiatan }\end{array}$ & Pokok Bahasan (Materi) & $\begin{array}{c}\text { Pemateri dan } \\
\text { Pemandu }\end{array}$ & $\begin{array}{c}\text { Waktu } \\
\text { Pelaksanaan }\end{array}$ \\
\hline Presentasi & $\begin{array}{c}\text { Manajemen Pemasaran Tempe } \\
\text { dan Hal Promosi dan Distribusi }\end{array}$ & Meilin Veronica & 2 Maret 2019 \\
\hline
\end{tabular}

Pelaksanaan program ini melibatkan 6 mahasiswa Prodi Manajemen agar kegiatan dapat berjalan lancar. Peran mahasiswa di dalam pelatihan ini adalah memberikan panduan tentang penggunaan aplikasi sosial media seperti Facebook, Instagram, WhatsApp, Gojek dan Grab serta memfasilitasi cara untuk menjadi rekan dari aplikasi gojek dan grab tersebut dan membantu peserta dalam mencari informasi distributor yang belum pernah kerjasama sebelumnya.

Kegiatan sesi tanya jawab dilakukan bersamaan dengan penyajian materi. Para peserta dapat langsung berdiskusi dengan para pemateri secara langsung untuk memahamkan materi dan sharing pengalaman terkait dengan masalah yang tengah dibahas dalam materi bersangkutan. Kegiatan ini dilaksanakan di lokasi usaha home industri Bapak Rohidin.

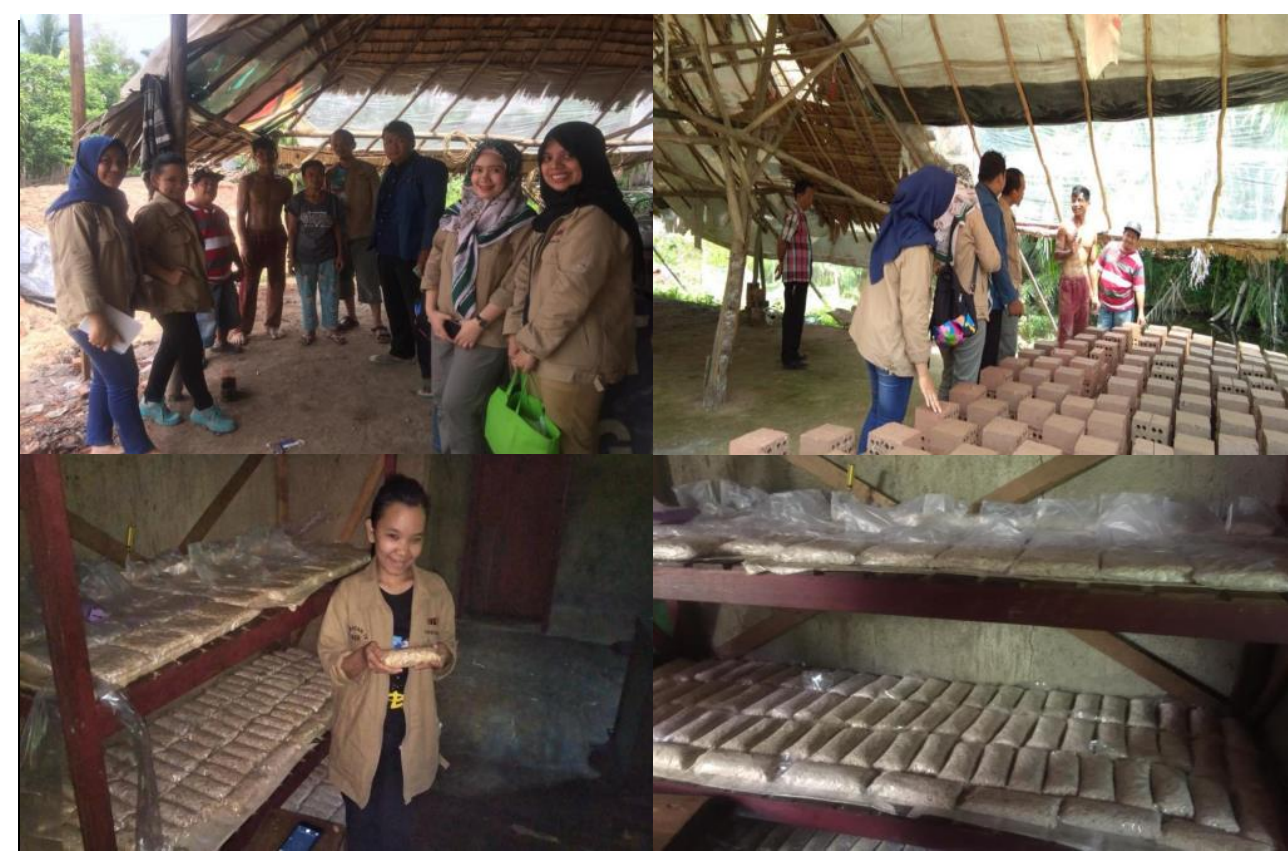

Gambar 1. Tempat usaha home indusrty Bapak Rohidin 


\subsection{Pembahasan}

\section{Pemasaran}

Pemasaran menurut Kotler dan Armstrong (2014:27) : Pemasaran adalah proses dimana perusahaan menciptakan nilai bagi pelanggan dan membangun hubungan yang kuat dengan pelanggan, dengan tujuan menangkap nilai dari pelanggan sebagai imbalannya.

Pengertian di atas memperlihatkan adanya suatu usaha untuk memenuhi kebutuhan serta adanya suatu usaha yang diarahkan untuk memperoleh kebutuhan tersebut dengan cara mengadakan hubungan dengan pihak lain.

2. Promosi

Promosi menurut Rangkuti (2009:49) : Promosi adalah salah satu unsur dalam bauran pemasaran perusahaan yang didayagunakan untuk memberitahukan, membujuk, dan mengingatkan tentang produk perusahaan.

Promosi menurut Kotler dan Armstrong (2014:77) : Promosi adalah aktivitas yang mengkomunikasikan keunggulan produk dan membujuk pelanggan untuk membeli produk itu.

Promosi penjualan menurut Kotler dan Armstrong (2014:501) : Promosi penjualan merupakan insentif jangka pendek untuk mendorong keinginan dan untuk mencoba atau membeli suatu produk/jasa.

Alat-alat promosi penjualan menurut Kotler dan Armstrong (2014:662) :

a. Contoh produk (sample) adalah tawaran produk tertentu untuk percobaan.

Sebelum adanya kegiatan pengabdian ini, mitra home industri tidak memberikan produk sample, dengan adanya pelatihan ini maka mitra home industri bisa memberikan produk sample sehingga konsumen mengetahui rasa dan kualitasnya.

b. Kemasan dengan harga potongan (price packs) adalah potongan harga yang ditandai oleh produsen secara langsung pada label atau kemasan. Ada yang berupa kemasan yang dijual dengan potongan harga (a reduced price packs).

Sebelum adanya kegiatan pengabdian ini, mitra home industri hanya memiliki satu jenis kemasan dengan harga yang sama tanpa potongan, dengan adanya pelatihan ini maka mitra home industri bisa membuat dua jenis kemasan dengan potongan dan tanpa potongan harga.

c. Bingkisan (premiums) adalah barang yang ditawarkan gratis atau dengan harga murah sebagai sebuah insentif bagi pembelian sebuah produk.

Sebelum adanya kegiatan pengabdian ini, mitra home industri tidak memberikan bingkisan atas pembelian dengan jumlah tertentu, dengan adanya pelatihan ini maka mitra home industri bisa memberikan bingkisan ketika pembeli membeli dengan jumlah yang banyak.

d. Diskon adalah pengurangan langsung terhadap harga atas pembelian selama satu periode tertentu.

Sebelum adanya kegiatan pengabdian ini, mitra home industri tidak memberikan diskon atas pembelian, dengan adanya pelatihan ini maka mitra home industri bisa memberikan diskon atas pembelian selama satu periode.

e. Barang gratis adalah memberi timbangan barang kepada para perantara, apabila mereka membeli sejumlah tertentu.

Sebelum adanya kegiatan pengabdian ini, mitra home industri tidak memberikan barang gratis atas pembelian sejumlah tertentu, dengan adanya pelatihan ini maka mitra home industri bisa memberikan barang gratis seperti beli 2 gratis 1 atau beli 1 gratis 1 .

Ada 5 (lima) strategi pemasaran terbaik yang harus dilakukan untuk meningkatkan penjualan produk :

3. Menggunakan Social Media

Social media adalah alat pemasaran yang paling ampuh karena hampir semua orang dari berbagai latar belakang yang berbeda, sangat aktif menggunakannya. Dengan social media, perusahaan dapat menjalin interaksi secara luas dengan berbagai kalangan, dengan biaya yang murah dan visibilitas atau keterlihatan yang tinggi. Social media juga memungkinkan perusahaan untuk memilih komunitas yang sesuai untuk memasarkan produk mereka, sehingga apa yang ditawarkan memiliki peluang besar untuk terjual.

Sebelum adanya kegiatan pengabdian ini, mitra home industri belum menggunakan social media secara maksimal tetapi setelah adanya pengabdian ini mitra home industri menjadi lebih paham dan akan menggunakan social media lebih maksimal lagi.

4. Memilih Tempat Strategis 
Tempat strategis masih menjadi salah satu strategi pemasaran yang patut dipertimbangkan, karena dengan tempat penjualan yang strategis berarti produk kita memiliki kemungkinan terlihat lebih tinggi dan tentu saja memicu penjualan yang tinggi. Kriteria pemilihan tempat strategis ini harus menyesuaikan dengan target sasaran serta kemudahan untuk menjangkaunya.

Sebelum adanya kegiatan pengabdian ini, lokasi mitra home industri belum dikatakan sebagai tempat strategis tetapi setelah adanya pengabdian ini mitra home industri menjadi lebih paham dan akan mencari lokasi lain sebagai tempat strategis untuk memasarkan produk tempe ini.

4. Memberi Insentif untuk Rekomendasi

Sebuah produk akan terlihat bagus dan dapat dipercaya bila ada yang merekomendasikannya. Untuk mendapat sebuah rekomendasi atau testimoni dari pelanggan yang telah memakai produk tersebut kita harus memberi penghargaan berupa insentif yang menarik. Insentif sebuah testimoni tidak harus selalu berupa uang, namun bisa berupa hadiah produk atau potongan harga. Dengan adanya insentif ini secara tidak langsung perusahaan memenangkan dua pihak untuk sasaran marketing, yaitu pelanggan yang loyal dan calon pelanggan.

Sebelum adanya kegiatan pengabdian ini, mitra home industri belum memberikan insentif bagi konsumen yang sudah merekomendasikan tetapi setelah adanya pengabdian ini mitra home industri menjadi lebih paham dan akan memberikan insentif kepada konsumen atau reseller atau perantara yang merekomendasikan produk tempe ini.

5. Menjalin Hubungan Baik dengan Pelanggan

Pelanggan yang loyal adalah sebuah aset penting perusahaan. Mereka telah berulangkali membeli produk kita dan ikut menyumbang pemasukan secara rutin. Jika tidak ingin kehilangan sebuah pembelian, di tengah persaingan banyaknya produk serupa, maka tidak ada salahnya kita memberi penghargaan kepada para pelanggan yang loyal terhadap perusahaan dengan cara menaggapi masukan pelanggan maupun memberi hadiah secara langsung atas pembelian yang mereka lakukan.

Sebelum adanya kegiatan pengabdian ini, mitra home industri belum menjalin hubungan baik dengan pelanggan secara maksimal tetapi setelah adanya pengabdian ini mitra home industri menjadi lebih paham dan akan mulai menjalin hubungan baik dengan pelanggan lebih maksimal lagi.

6. Distribusi

Menurut Tjiptono (2014:295), "Saluran distribusi merupakan serangkaian partisipan organisasional yang melakukan semua fungsi yang dibutuhkan untuk menyampaikan produk/jasa dari penjual ke pembeli akhir."

Menurut Daryanto (2011 : 63) distribusi adalah "suatu perangkat organisasi yang saling bergantung dalam menyediakan satu produk untuk digunakan atau dikonsumsi oleh konsumen/pengguna".

Menurut Gitosudarmo (2012 : 177) saluran distribusi dapat dibedakan menjadi tiga, yaitu :

a. Saluran distribusi intensif adalah distribusi di mana barang yang dipasarkan itu diusahakan agar dapat menyebar seluas mungkin hingga dapat secara intensif menjangkau semua lokasi dimana calon konsumen berada.

b. Saluran distribusi selektif adalah distribusi di mana barang- barang hanya disalurkan oleh beberapa penyalur saja yang terpilih atau selektif.

c. Saluran distribusi ekslusif adalah bentuk penyaluran yang hanya menggunakan penyalur yang sangat terbatas jumlahnya bahkan pada umumnya hanya ada satu penyalur tunggal untuk satu daerah tertentu.

Sebelum adanya kegiatan pengabdian ini, mitra home industri hanya menggunakan saluran distribusi ekslusif yang hanya menggunakan penyalur satu penyalur tunggal untuk satu daerah tertentu, dengan adanya pelatihan ini maka usaha home industry Bapak Rohidin bisa menggunakan saluran distribusi intensif dimana barang yang dipasarkan bisa menyebarluas dan dapat menjangkau semua lokasi dimana calon konsumen berada.

\section{KESIMPULAN}

\subsection{Kesimpulan}

Berdasar hasil pelaksanaan kegiatan pengabdian kepada masyarakat ini dan uraian pembahasan di atas, dapat disimpulkan beberapa hal sebagai berikut : 
1. Pelatihan ini memberikan beberapa materi yang terkait dengan upaya mengembangkan jalur promosi dan distribusi ke masyarakat yang lebih luas lagi tidak hanya disekitaran Kelurahan Talang Jambe.

2. Materi wawasan dan praktikum pelatihan yang disajikan dapat diterima, dicerna, dan dipahami peserta dengan baik.

3. Kegiatan berlangsung lancar, tepat waktu dan sesuai dengan yang diharapkan dan para peserta

\subsection{Saran}

Program pelatihan ini sangat bermanfaat dalam upaya meningkatkan wawasan dan pengetahuan para wirausahawan dalam mempromosikan dan mendistribusikan tempe.

Beberapa saran yang dapat diterapkan, yakni :

1. Menggunakan beberapa alat promosi penjualan seperti memberikan sample produk, kemasan dengan potongan harga, bingkisan, diskon dan barang gratis,

2. Menggunakan sosial media

3. Memilih tempat strategis

4. Memberikan insentif untuk rekomendasi

5. Menjalin hubungan baik dengan pelanggan

6. Mengembangkan jalur distribusi intensif

\section{UCAPAN TERIMA KASIH}

Tim Pengabdi Pada Masyarakat UIGM menyampaikan ucapan terima kasih yang sebesar-besarnya atas kerjasama dalam pelaksanaan kegiatan PPM tersebut, kepada :

1. Fakultas Ekonomi UIGM

2. Lembaga Penelitan dan Pengabdian Masyarakat UIGM

3. Ketua RT 04 Talang Jambe dan Bapak Rohidin selaku pemilik usaha tempe

4. Para Mahasiswa Prodi Manajemen

\section{DAFTAR PUSTAKA}

Kotler, P., Kartajaya, H., Setiawan, I., 2010, Marketing 3.0, 36, John Wiley and Sons Inc., New Jersey Kotler, Amstrong. 2001. Prinsip-prinsip pemasaran, Edisi keduabelas, Jilid 1. Jakarta: Erlangga Basu Swastha.2002.Manajemen Pemasaran. Edisi Kedua. Cetakan Kedelapan. Jakarta: Penerbit Liberty Fandy, Tjiptono. 2014. Pemasaran Jasa. Andi : Yogyakarta

Daryanto. 2011. Manajemen Pemasaran: Sari Kuliah. Bandung: Satu Nusa.

Gitosudarmo Indriyo. 2012. Manajemen Pemasaran. edisi kedua, cetakan kedua. Penerbit : BPFE Yogyakarta.

Kotler, Philip dan Amstrong, Gary. 2014. Principles of Marketin, 12th Edition. Jilid 1 Terjemahan Bob Sabran Jakarta : Erlangga.

Rangkuti, Freddy. 2009. Strategi Promosi yang Kreatif dan Analisis Kasus Integrated Marketing Communication. Jakarta : PT. Gramedia Pustaka Utama 